https://helda.helsinki.fi

An 8-year surveillance of the diversity and persistence of Listeria monocytogenes in a chilled food processing plant analyzed by amplified fragment length polymorphism.

Keto-Timonen, $\mathrm{R}$.

2007

Journal of Food Protection. 2007; 70(8): 1866-1873

http://hdl.handle.net/1975/7371

Downloaded from Helda, University of Helsinki institutional repository.

This is an electronic reprint of the original article.

This reprint may differ from the original in pagination and typographic detail.

Please cite the original version. 


\title{
An 8-Year Surveillance of the Diversity and Persistence of Listeria monocytogenes in a Chilled Food Processing Plant Analyzed by Amplified Fragment Length Polymorphism
}

\author{
RIIKKA KETO-TIMONEN,* RIINA TOLVANEN, JANNE LUNDÉN, AND HANNU KORKEALA \\ Department of Food and Environmental Hygiene, Faculty of Veterinary Medicine, P.O. Box 66, FI-00014 University of Helsinki, Finland
}

MS 07-061: Received 2 February 2007/Accepted 6 April 2007

\begin{abstract}
Contamination routes of Listeria monocytogenes were examined in a chilled food processing plant that produced readyto-eat and ready-to-reheat meals during an 8-year period by amplified fragment length polymorphism (AFLP) analysis. A total of 319 L. monocytogenes isolates were recovered from raw materials $(n=18)$, the environment $(n=77)$, equipment $(n=$ 193), and products $(n=31)$, and 18 different AFLP types were identified, five of which were repeatedly found to be persistent types. The three compartments (I to III) of the plant showed markedly different contamination statuses. Compartment I, which produced cooked meals, was heavily contaminated with three persistent AFLP types. AFLP type A1 dominated, and it comprised $93 \%$ of the isolates of the compartment. Compartment II, which produced uncooked chilled food, was contaminated with four persistent and five nonpersistent AFLP types. The equipment of compartment III, which produced cooked ready-toreheat meals, was free of contamination. In compartments that produced cooked meals, the cleaning routines, product types, and lack of compartmentalization seemed to predispose production lines to persistent contamination. The most contaminated lines harbored L. monocytogenes in coolers, conveyors, and packing machines. Good compartmentalization limited the flow of L. monocytogenes into the postheat-treatment area and prevented the undesired movement of equipment and personnel, thus protecting the production lines from contamination. In compartment II, grated cheese was shown to cause product contamination. Therefore, special attention should be paid to continuous quality control of raw ingredients when uncooked ready-toeat foods are produced. In compartment II, reconstruction of the production line resulted in reduced prevalence rates of $L$. monocytogenes and elimination of two persistent AFLP types.
\end{abstract}

During the past decade, consumer demand for foods requiring minimal preparation time has increased the readyto-eat and ready-to-reheat chilled food markets. For the chilled food processing industry, contamination of products with Listeria monocytogenes is a major safety concern because the bacterium is widely spread in the environment, can grow at refrigerated temperatures, and may cause persistent plant contamination $(10,12,19,29)$. In addition, some chilled food products are consumed without further heating or without adequate reheating to destroy L. monocytogenes, and therefore, these products can serve as sources of human listeriosis in outbreaks and sporadic cases.

A number of studies have shown that $L$. monocytogenes contamination of food products primarily results from postprocessing contamination from the equipment and the processing environment $(3,5,19,24,26)$, although the initial contamination may be introduced to the production plant via raw materials (17). The contamination routes of L. monocytogenes in the processing environment have been examined in several studies targeting meat, poultry, and fish processing plants $(3,7,29,31)$. However, despite the increased consumption of ready meals, insufficient information is available on the contamination patterns of L. monocytogenes in plants that produce ready-to-eat and ready-to-

* Author for correspondence. Tel: +358-9-19157145; Fax: +358-9-

19157170; E-mail: riikka.keto-timonen@helsinki.fi. reheat meals. These products are composed of multiple raw ingredients, and each product type has a distinct preparation process. Therefore, the contamination pattern of L. monocytogenes can be hypothesized to vary between different processing lines, even within a single processing plant. Because recognition of the sources of contamination is a key focus in the control of L. monocytogenes, further research is needed to enable the production of L. monocytogenesfree chilled ready meals.

Amplified fragment length polymorphism (AFLP) is a genotyping method that is highly suited to screening large numbers of isolates and creating fingerprinting databases $(13,30)$. AFLP analysis has proven to be an efficient genotyping method for L. monocytogenes $(11,15)$, and it has been applied to a subset of isolates in a contamination study of fish slaughterhouses and smokehouses (31). However, the method has not been previously utilized in extensive contamination route studies of L. monocytogenes.

We examined the contamination routes of L. monocytogenes in a chilled food processing plant that produced ready-to-eat and ready-to-reheat foods, such as pizzas, pasties, and ready meals, over an 8-year period. Factors affecting the occurrence and persistence of $L$. monocytogenes in different compartments and lines of the plant were identified. In addition, we assessed possible sources of initial contamination and evaluated the effect of different inter- 
TABLE 1. Product types manufactured in different compartments and degree of compartmentalization

\begin{tabular}{|c|c|c|c|}
\hline $\begin{array}{c}\text { Compart- } \\
\text { ment }\end{array}$ & $\begin{array}{l}\text { Processing } \\
\text { line }\end{array}$ & Product type & Compartmentalization \\
\hline I & $\begin{array}{c}\mathrm{A}, \mathrm{B}, \mathrm{C} \\
\mathrm{D}, \mathrm{E}\end{array}$ & $\begin{array}{l}\text { Cooked ready-to-eat } \\
\text { Cooked ready-to-re- } \\
\text { heat } \\
\text { Uncooked products } \\
\text { requiring cooking } \\
\text { before consump- } \\
\text { tion }^{a}\end{array}$ & $\begin{array}{l}\text { Raw and postheat- } \\
\text { treatment areas } \\
\text { not separated in } \\
\text { 1998-1999 } \\
\text { Raw and postheat- } \\
\text { treatment areas } \\
\text { separated in } \\
\text { 2000-2006 }\end{array}$ \\
\hline II & $\mathrm{F}$ & $\begin{array}{l}\text { Ready-to-eat }{ }^{b} \\
\text { Ready-to-reheat }{ }^{b}\end{array}$ & $\begin{array}{l}\text { No compartmentali- } \\
\text { zation }\end{array}$ \\
\hline III & $\mathrm{G}, \mathrm{H}$ & $\begin{array}{l}\text { Cooked ready-to-re- } \\
\text { heat }\end{array}$ & $\begin{array}{l}\text { Raw and postheat- } \\
\text { treatment areas } \\
\text { separated }\end{array}$ \\
\hline
\end{tabular}

${ }^{a}$ Uncooked products were produced in line B until the year 2000.

${ }^{b}$ Products were composed of various cooked and uncooked ingredients, such as meat, fish, bakery products, vegetables, and dairy products, which originated from different producers. The finished products were not cooked in the plant.

ventions on the occurrence of $L$. monocytogenes. Isolates were characterized by AFLP, and the suitability of AFLP analysis for contamination route studies of L. monocytogenes was also evaluated.

\section{MATERIALS AND METHODS}

Food processing plant. The food processing plant was divided into three compartments (I, II, and III) with differing degrees of compartmentalization (Table 1). A wide variety of raw materials, including meat, fish, vegetables, dairy products, and flour, were used for the production of ready-to-eat and ready-toreheat chilled meals as well as for meals requiring cooking before consumption. In compartment I, cooked chilled meals, such as pizzas and pasties with different fillings, were produced in five different production lines (A to E), whereas in compartment II, nonheat-treated chilled meals were produced in one processing line (F). Compartment III produced cooked ready-to-reheat meals and had two production lines ( $\mathrm{G}$ and $\mathrm{H})$. Compartment III had been used only for the production of cooked meals, while in compartment I, uncooked products requiring cooking before consumption were also produced in line B until 2000. The plant utilized job rotation between departments; however, over the course of 1 production day, assigned duties were rotated only within a single department. The cleaning services of the plant were outsourced.

L. monocytogenes isolates and collection of sampling data. A total of 319 L. monocytogenes isolates were obtained during an 8-year period (May 1998 to July 2006) as part of a quality control program in a chilled food processing plant. During the surveillance, the sampling scheme of the quality control program was adjusted to the prevailing situation in the plant. In general, basic sampling was carried out on each line at least weekly. If L. monocytogenes was recovered, additional sampling was performed. Sampling was especially targeted to postheating areas and sites that had in earlier samplings tested positive for L. monocytogenes or were difficult to clean because of poor hygienic design of equipment. Samples were collected during production and after cleaning and disinfection. A small-scale sampling was carried out in 1998 and 1999, but information about the total number of samples analyzed is lacking; an extensive sampling scheme was established in 2000. A total of 4,554 equipment and environmental samples and 879 product and raw material samples were collected between 1 January 2000 and 31 July 2006 (Table 2). At the beginning of 2005, the sampling procedure was modified; pooled samples were collected from equipment, and thus, the total number of samples decreased, although the same sites were targeted. Detection of L. monocytogenes was carried out in a two-step enrichment procedure according to the International Organization for Standardization guidelines (2). Identification was based on Gram staining, hemolytic activity, catalase reaction, and motility at $25^{\circ} \mathrm{C}$ and confirmed with an API Listeria kit (bioMérieux SA, Marcy

TABLE 2. Collected equipment and environmental samples; raw material and product samples; and the isolation rate of L. monocytogenes $^{a}$

\begin{tabular}{|c|c|c|c|c|c|c|c|c|c|c|c|c|}
\hline \multirow[b]{4}{*}{ Year } & \multicolumn{9}{|c|}{ Equipment and environment } & & & \\
\hline & \multicolumn{3}{|c|}{ Compartment I } & \multicolumn{3}{|c|}{ Compartment II } & \multicolumn{3}{|c|}{ Compartment III } & \multicolumn{3}{|c|}{ Products and raw materials } \\
\hline & \multirow{2}{*}{$\begin{array}{l}\text { No. of } \\
\text { samples }\end{array}$} & \multicolumn{2}{|c|}{$\begin{array}{c}\text { L. monocytogenes } \\
\text { isolates }\end{array}$} & \multirow{2}{*}{$\begin{array}{l}\text { No. of } \\
\text { samples }\end{array}$} & \multicolumn{2}{|c|}{$\begin{array}{c}\text { L. monocytogenes } \\
\text { isolates }\end{array}$} & \multirow{2}{*}{$\begin{array}{c}\text { No. of } \\
\text { samples }\end{array}$} & \multicolumn{2}{|c|}{$\begin{array}{c}\text { L. monocytogenes } \\
\text { isolates }\end{array}$} & \multirow{2}{*}{$\begin{array}{l}\text { No. of } \\
\text { samples }\end{array}$} & \multicolumn{2}{|c|}{$\begin{array}{c}\text { L. monocytogenes } \\
\text { isolates }\end{array}$} \\
\hline & & $n$ & $\%$ & & $n$ & $\%$ & & $n$ & $\%$ & & $n$ & $\%$ \\
\hline 1998 & NA & 5 & NA & NA & 1 & NA & $\mathrm{NA}$ & 0 & NA & NA & 0 & NA \\
\hline 1999 & NA & 1 & NA & NA & 1 & NA & NA & 0 & NA & NA & 0 & NA \\
\hline 2000 & 517 & 11 & 2.1 & 419 & 27 & 6.4 & 143 & ND & 0.0 & 252 & 25 & 9.9 \\
\hline 2001 & 447 & 9 & 2.0 & 302 & 13 & 4.3 & 115 & ND & 0.0 & 229 & 19 & 8.3 \\
\hline 2002 & 491 & 48 & 9.8 & 236 & 8 & 3.4 & 111 & ND & 0.0 & 155 & 3 & 1.9 \\
\hline 2003 & 368 & 34 & 9.2 & 171 & 19 & 11.1 & 88 & $\mathrm{ND}$ & 0.0 & 93 & 1 & 1.1 \\
\hline 2004 & 327 & 42 & 12.8 & 139 & 19 & 13.7 & 95 & ND & 0.0 & 55 & 1 & 1.8 \\
\hline $2005^{b}$ & 211 & 20 & 9.5 & 59 & 3 & 5.1 & 54 & $\mathrm{ND}$ & 0.0 & 59 & ND & 0.0 \\
\hline $2006^{b, c}$ & 179 & 7 & 3.9 & 43 & 1 & 2.3 & 39 & 1 & 2.6 & 36 & ND & 0.0 \\
\hline $2000-2006$ & 2,540 & 171 & 6.7 & 1,369 & 90 & 6.6 & 645 & 1 & 0.2 & 879 & 49 & 5.6 \\
\hline
\end{tabular}

${ }^{a}$ NA, no data available; ND, not detected.

${ }^{b}$ Pooled equipment and environmental samples were collected during 2005 and 2006.

${ }^{c}$ Samples were collected between 1 January 2006 and 31 July 2006. 
l'Etoile, France). Isolates originated from equipment ( $n=193)$, the processing environment $(n=77)$, products $(n=31)$, and raw materials $(n=18)$. Sample data were obtained from the sampling records of the plant.

DNA extraction. DNA was extracted as described previously by Pitcher et al. (22), with slight modifications. The cells were lysed in TE (10 mM Tris- $\mathrm{HCl}$ and $1 \mathrm{mM}$ EDTA) with lysozyme at $24.5 \mathrm{mg} / \mathrm{ml}$ (Sigma, St. Louis, Mo.), mutanolysin at $245 \mathrm{IU} / \mathrm{ml}$ (Sigma), and RNase at $196 \mu \mathrm{g} / \mathrm{ml}$ (Sigma) at $37^{\circ} \mathrm{C}$ for $2 \mathrm{~h}$. DNA concentrations were measured with a BioPhotometer (Eppendorf, Hamburg, Germany). DNA was stored at $-70^{\circ} \mathrm{C}$.

AFLP analysis. AFLP analysis was performed as described previously (13), with some modifications. Briefly, the purified total DNA (400 ng) was digested with 15 U of HindIII (New England Biolabs, Beverly, Mass.) and $15 \mathrm{U}$ of HpyCH4IV (New England Biolabs) and ligated to restriction site-specific adapters as described earlier. Samples were stored at $-20^{\circ} \mathrm{C}$ prior to PCR amplification.

DNA samples were diluted with sterile, distilled, deionized water (1:2) prior to preselective PCR amplification, which was performed in a $20-\mu l$ reaction mixture containing $4 \mu \mathrm{l}$ of diluted template DNA, $15 \mu \mathrm{l}$ of Amplification Core Mix (Applied Biosystems, Foster City, Calif.), 25 nM Hind-0 primer (5'-GACTGCG TACCAGCTT-3'; Oligomer, Helsinki, Finland), and $125 \mathrm{nM}$ Hpy-0 primer (5'-CGATGAGTCCTGACCGT-3'; Oligomer). After preselective amplification, the templates were diluted with sterile, distilled, deionized water (1:20) and amplified by selective PCR in a $10-\mu$ l reaction mixture containing $1.5 \mu$ l of diluted template, $50 \mathrm{nM}$ FAM-labeled Hind-A primer (5'-GACTGCGT ACCAGCTTA-3'; Oligomer), $250 \mathrm{nM}$ Hpy-A primer (5'-CGAT GAGTCCTGACCGTA-3'; Oligomer), and $7.5 \mu \mathrm{l}$ of Amplification Core Mix (Applied Biosystems). Preselective and selective PCR conditions were as described previously (13).

The samples were prepared for capillary electrophoresis by adding $1 \mu \mathrm{l}$ of the selective amplification product to $11.5 \mu \mathrm{l}$ of Hi-Di Formamide (Applied Biosystems) and $0.5 \mu l$ of the internal size standard (GS-500 LIZ, Applied Biosystems) to enable accurate band sizing. The mixture was denatured at $95^{\circ} \mathrm{C}$ for $2 \mathrm{~min}$. Denatured fragments were electrophoresed on POP-4 polymer (Applied Biosystems) with an ABI PRISM 310 Genetic Analyzer (Applied Biosystems) in $1 \times$ Genetic Analyzer Buffer with EDTA (Applied Biosystems). The electrophoresis conditions were $15 \mathrm{kV}$ at $60^{\circ} \mathrm{C}$ for $28 \mathrm{~min}$. GeneScan 3.7 fragment analysis software (Applied Biosystems) was used for data preprocessing.

Reproducibility among different data sets was assessed with L. monocytogenes strain ATCC 15313 as an internal reference, which underwent each step of the DNA extraction and AFLP analysis a total of 46 times, thereby providing a standard for comparison.

In situ DNA isolation and PFGE. In situ DNA isolation and pulsed-field gel electrophoresis (PFGE) were performed for selected strains $(n=48)$ as described by Lundén et al. (19). Two restriction enzymes, $A p a \mathrm{I}$ and $A s c \mathrm{I}$ (New England Biolabs), were used.

AFLP pattern analysis. AFLP and PFGE patterns were analyzed by BioNumerics software 4.6 (Applied Maths, Sint-Martens-Latem, Belgium). Similarity between normalized AFLP patterns (range, 75 to $500 \mathrm{bp}$ ) was calculated with the Pearson product-moment correlation coefficient. Similarity between ApaI and AscI macrorestriction patterns, based on band positions, was expressed as a Dice coefficient correlation. Clustering and construc- tion of dendrograms were performed by the unweighted pairgroup method with arithmetic averages.

Serotyping. One to three strains from each AFLP type were serotyped with commercial antisera (Denka Seiken, Tokyo, Japan) according to the manufacturer's instructions.

Strain persistence. L. monocytogenes strains were considered persistent when they were found repeatedly (three times or more) in the environment or on equipment over a minimum of a 3 -month period. Strains that were isolated sporadically (fewer than three times) or within a shorter time period ( $<3$ months) were considered nonpersistent.

\section{RESULTS}

Subtyping of $L$. monocytogenes isolates. During the 8-year surveillance, a total of 319 L. monocytogenes isolates were collected. L. monocytogenes was recovered from equipment and environmental samples, which were taken both during production and after cleaning and disinfection. The isolates were divided into 18 different AFLP types (A1 through A18) and four serotypes (1/2a, 1/2b, 1/2c, and 4b) (Fig. 1). Serotype 1/2a predominated, and all equipment and environmental isolates, with the exception of one equipment isolate, belonged to this serotype. Serotype $1 / 2 b$ was detected in raw material, serotype $1 / 2 \mathrm{c}$ was detected in raw material and equipment, and serotype $4 \mathrm{~b}$ was detected in raw material and finished products. Five AFLP types were persistent (Table 3).

\section{L. monocytogenes contamination patterns in com-} partment I. In compartment I, sampling was targeted to postcooking sites. A total of 177 isolates, which represented $66 \%$ of all environmental and equipment isolates of the plant, were recovered from the environment $(n=45)$ and equipment ( $n=132$ ) of this compartment (Table 4$)$. The isolation rate of $L$. monocytogenes varied between 2.0 and $12.8 \%$ in different years (Table 2 ). The most contaminated lines were A and B, with 99 and 59 isolates recovered, respectively. Frequently contaminated sites were conveyors after coolers and packing machines. In line $\mathrm{B}$, also, the cooler was recurrently contaminated. In lines $\mathrm{C}, \mathrm{D}$, and $\mathrm{E}$, the number of L. monocytogenes-positive samples was 6 , 6 , and 7 , respectively. Isolates of compartment I were divided into three different AFLP types (A1, A11, and A14), all of which were persistent. AFLP type A1 clearly dominated, was repeatedly isolated in successive months, and persisted throughout the 8-year surveillance (Table 3), and it comprised $93 \%$ of the isolates of the compartment. AFLP type A1 was not, however, recovered from finished products. The prevalence of AFLP type A1 in samples collected from compartment I was significantly higher $(P<0.01$, chi-square test) than the prevalence in samples collected from compartments II or III. Type A1 was also significantly more common $(P<0.05$, Fisher exact test $)$ in lines $\mathrm{A}$ and B than in lines C, D, and E. AFLP type A11 was specific to compartment I, whereas AFLP type A1 was recovered from all three compartments of the plant, and A14 was isolated from compartments I and II.

During the surveillance period, a new packing machine was purchased for lines A (in 2005) and B (in 2003). Soon 
Similarity \%

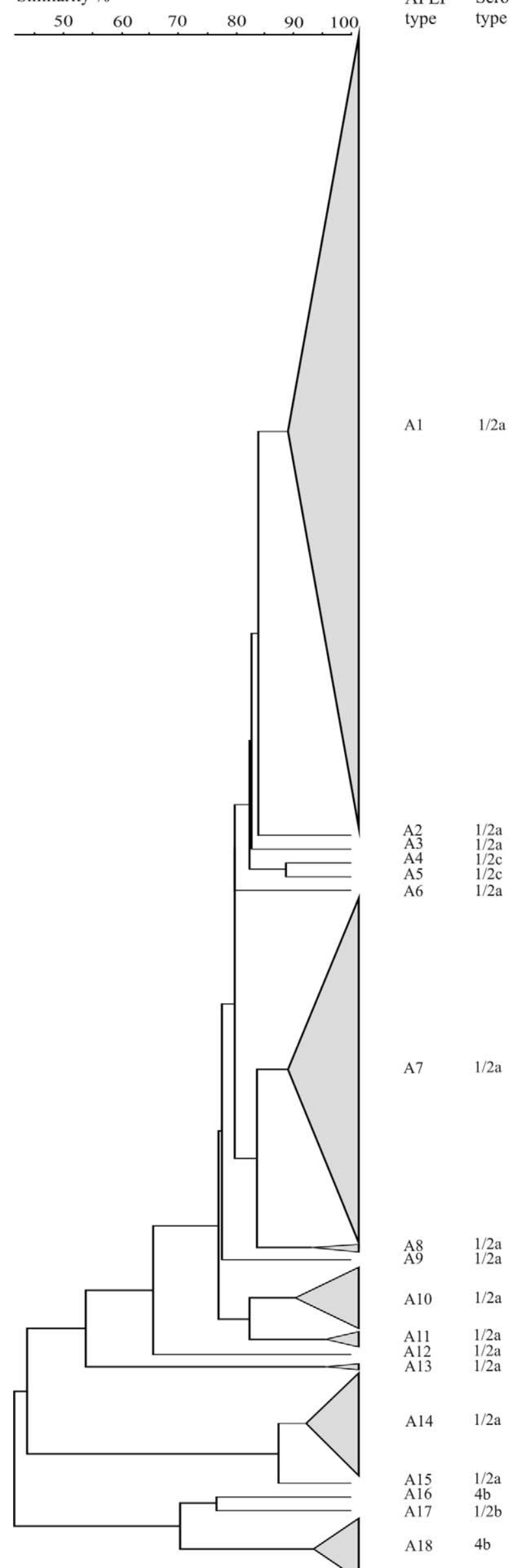

after the new packing machines were used, they were found to be contaminated with the predominant AFLP type, A1 The original packing machine of line A was dismantled, cleaned, and disinfected and then relocated to line $\mathrm{E}$ at the beginning of 2006. No L. monocytogenes was recovered from the packing machine during the final 7 months of the surveillance.

L. monocytogenes contamination patterns in compartment II. A total of $92 \mathrm{~L}$. monocytogenes-positive samples were detected in compartment II (Table 4). The isolation rate varied between 2.3 and $13.7 \%$ in different years (Table 2). The L. monocytogenes prevalence did not differ significantly ( $P=0.85$, chi-square test) between compartments I and II. AFLP analysis divided isolates into nine different AFLP types, of which four were persistent (A1, A7, A10, and A14), and five were nonpersistent (A3, A5, A8, A9, and A13). All nonpersistent AFLP types and persistent AFLP types A7 and A10 were specific to this compartment. AFLP type A7 dominated in compartment II and was repeatedly isolated in successive months. The most contaminated sites were conveyor before cooler, cooler, and packing machine.

L. monocytogenes contamination pattern in compartment III. During the 8-year surveillance, only one $L$. monocytogenes isolate was recovered from compartment III (Table 4), with the isolation rate varying between 0 and $2.6 \%$ in different years (Table 2). The organism was isolated from a movable container and belonged to persistent AFLP type A1. The L. monocytogenes prevalence in samples collected from compartment III was significantly lower $(P<0.01$, chi-square test $)$ than in samples collected from compartment I or II.

L. monocytogenes in raw materials and products. Raw materials and finished products were positive for $L$. monocytogenes 18 and 31 times, respectively. The isolation rate varied between 0 and $9.9 \%$ in different years (Table $2)$. The contaminated raw ingredients were grated cheese $(n=10)$, sweet pepper (capsicum) $(n=7)$, and a cooked chicken product $(n=1)$. Raw material isolates belonged to eight different AFLP types, of which seven were nonpersistent, and one was persistent (Table 3). In finished products, four nonpersistent (A2, A12, A13, and A18) and three persistent (A7, A10, and A14) AFLP types were observed. All isolates were recovered from finished products that were nonheat treated and produced in compartment II.

AFLP type A18 was isolated from both raw materials (grated cheese) and finished products produced in compartment II a total of 13 times over a 3-month period (from December 2000 to March 2001). The supplier of the cheese

$\leftarrow$

FIGURE 1. A simplified dendrogram of AFLP profiles of $\mathrm{L}$. monocytogenes strains $(\mathrm{n}=319)$. Shaded clusters contain AFLP patterns showing $>89 \%$ similarity (cutoff similarity value). A similarity analysis was performed by the Pearson product-moment correlation coefficient, and clustering was performed by the unweighted pair-group method with arithmetic averages. 
TABLE 3. Listeria monocytogenes AFLP types and serotypes recovered from the food processing plant

\begin{tabular}{|c|c|c|c|c|c|c|c|c|c|c|}
\hline \multirow[b]{2}{*}{$\begin{array}{l}\text { AFLP } \\
\text { type }\end{array}$} & \multirow[b]{2}{*}{ Serotype } & \multirow[b]{2}{*}{$\begin{array}{l}\text { Total no. } \\
\text { of isolates }\end{array}$} & \multirow[b]{2}{*}{ Compartment $^{a}$} & \multirow{2}{*}{$\begin{array}{c}\text { Contaminated } \\
\text { processing } \\
\text { line }^{b}\end{array}$} & \multirow[b]{2}{*}{$\begin{array}{l}\mathrm{P} \text { or } \\
\mathrm{NP}^{c}\end{array}$} & \multirow[b]{2}{*}{$\begin{array}{l}\text { Contamination time } \\
\text { span }(\mathrm{mo} / \mathrm{yr})\end{array}$} & \multicolumn{4}{|c|}{ No. of isolates } \\
\hline & & & & & & & $\begin{array}{c}\text { Environ- } \\
\text { ment }\end{array}$ & Equipment & Product & $\begin{array}{c}\text { Raw } \\
\text { material }\end{array}$ \\
\hline A1 & $1 / 2 \mathrm{a}$ & 174 & I, II, III & $\mathrm{A}, \mathrm{B}, \mathrm{C}, \mathrm{D}, \mathrm{E}, \mathrm{F}, \mathrm{G}$ & $\mathrm{P}$ & 09/98-07/06 & 46 & 128 & 0 & 0 \\
\hline $\mathrm{A} 2$ & $1 / 2 \mathrm{a}$ & 1 & II & ND & NP & $10 / 01$ & 0 & 0 & 1 & 0 \\
\hline A3 & $1 / 2 \mathrm{a}$ & 1 & II & $\mathrm{F}$ & NP & $11 / 00$ & 0 & 1 & 0 & 0 \\
\hline A4 & $1 / 2 \mathrm{c}$ & 1 & DR & ND & NP & 03/04 & 0 & 0 & 0 & 1 \\
\hline A5 & $1 / 2 \mathrm{c}$ & 1 & II & $\mathrm{F}$ & NP & 07/06 & 0 & 1 & 0 & 0 \\
\hline A6 & $1 / 2 \mathrm{a}$ & 1 & DR & ND & NP & $09 / 00$ & 0 & 0 & 0 & 1 \\
\hline A7 & $1 / 2 \mathrm{a}$ & 76 & II & $\mathrm{F}$ & $\mathrm{P}$ & 06/00-04/05 & 20 & 33 & 19 & 4 \\
\hline A8 & $1 / 2 \mathrm{a}$ & 2 & II & $\mathrm{F}$ & NP & 06/00-08/04 & 0 & 1 & 0 & 1 \\
\hline A9 & $1 / 2 \mathrm{a}$ & 1 & II & $\mathrm{F}$ & NP & $11 / 03$ & 0 & 1 & 0 & 0 \\
\hline A10 & $1 / 2 \mathrm{a}$ & 14 & II & $\mathrm{F}$ & $\mathrm{P}$ & 05/98-03/05 & 4 & 9 & 1 & 0 \\
\hline A11 & $1 / 2 \mathrm{a}$ & 4 & I & $A, B, D$ & $\mathrm{P}$ & 01/03-11/04 & 1 & 3 & 0 & 0 \\
\hline A12 & $1 / 2 \mathrm{a}$ & 1 & II & ND & NP & $03 / 02$ & 0 & 0 & 1 & 0 \\
\hline A13 & $1 / 2 \mathrm{a}$ & 2 & II & $\mathrm{F}$ & NP & $10 / 01$ & 0 & 1 & 1 & 0 \\
\hline A14 & $1 / 2 \mathrm{a}$ & 23 & I, II & $\mathrm{A}, \mathrm{C}, \mathrm{D}, \mathrm{F}$ & $\mathrm{P}$ & 09/00-10/05 & 6 & 15 & 2 & 0 \\
\hline A15 & $1 / 2 \mathrm{a}$ & 1 & DR & ND & NP & $08 / 00$ & 0 & 0 & 0 & 1 \\
\hline A16 & $4 \mathrm{~b}$ & 1 & DR & ND & NP & $06 / 00$ & 0 & 0 & 0 & 1 \\
\hline A17 & $1 / 2 b$ & 1 & DR & ND & NP & 04/02 & 0 & 0 & 0 & 1 \\
\hline A18 & $4 \mathrm{~b}$ & 14 & II & ND & NP & $12 / 00-08 / 02$ & 0 & 0 & 6 & 8 \\
\hline
\end{tabular}

${ }^{a} \mathrm{DR}$, detected only in raw materials.

${ }^{b} \mathrm{ND}$, not detected in the processing line.

${ }^{c}$ Persistent (P) or nonpersistent (NP) AFLP type.

TABLE 4. Listeria monocytogenes AFLP types found in different processing lines

\begin{tabular}{|c|c|c|c|c|c|c|}
\hline \multirow[b]{2}{*}{ Compartment $^{a}$} & \multirow[b]{2}{*}{ Line } & \multirow[b]{2}{*}{$\begin{array}{l}\text { No. of } \\
\text { isolates }\end{array}$} & \multirow[b]{2}{*}{$\begin{array}{c}\text { AFLP } \\
\text { type }\end{array}$} & \multicolumn{2}{|c|}{ No. of isolates } & \multirow{2}{*}{$\begin{array}{l}\text { Persistent or } \\
\text { nonpersistent } \\
\text { AFLP type }\end{array}$} \\
\hline & & & & $\begin{array}{c}\text { Environ- } \\
\text { ment }\end{array}$ & $\begin{array}{c}\text { Equip- } \\
\text { ment }\end{array}$ & \\
\hline \multirow[t]{12}{*}{$\mathrm{I}(n=177)$} & A & 99 & A1 & 24 & 72 & Persistent \\
\hline & & & A11 & 0 & 1 & Persistent \\
\hline & & & A14 & 2 & 0 & Persistent \\
\hline & $\mathrm{B}$ & 59 & A1 & 12 & 46 & Persistent \\
\hline & & & A11 & 1 & 0 & Persistent \\
\hline & $\mathrm{C}$ & 6 & A1 & 1 & 2 & Persistent \\
\hline & & & A14 & 1 & 2 & Persistent \\
\hline & $\mathrm{D}$ & 6 & A1 & 1 & 2 & Persistent \\
\hline & & & A11 & 0 & 2 & Persistent \\
\hline & & & A14 & 0 & 1 & Persistent \\
\hline & $\mathrm{E}$ & 7 & A1 & 3 & 2 & Persistent \\
\hline & & & A14 & 0 & 2 & Persistent \\
\hline \multirow[t]{9}{*}{ II $(n=92)$} & $\mathrm{F}$ & 92 & A1 & 4 & 4 & Persistent \\
\hline & & & A3 & 0 & 1 & Nonpersistent \\
\hline & & & A5 & 0 & 1 & Nonpersistent \\
\hline & & & A7 & 20 & 33 & Persistent \\
\hline & & & A8 & 0 & 1 & Nonpersistent \\
\hline & & & A9 & 0 & 1 & Nonpersistent \\
\hline & & & A10 & 4 & 9 & Persistent \\
\hline & & & A13 & 0 & 1 & Nonpersistent \\
\hline & & & A14 & 3 & 10 & Persistent \\
\hline \multirow[t]{2}{*}{ III $(n=1)$} & G & 1 & A1 & 1 & 0 & Persistent \\
\hline & $\mathrm{H}$ & 0 & $\mathrm{ND}^{b}$ & 0 & 0 & ND \\
\hline
\end{tabular}

a Total number of isolates in parentheses.

${ }^{b} \mathrm{ND}$, L. monocytogenes not detected in the processing line. was replaced, after which AFLP type A18 was detected only once, when a sample batch of grated cheese was purchased from a different supplier 17 months later. This $L$. monocytogenes-positive batch was discarded, i.e., it was not used for production.

Only one persistent AFLP type (A7) was recovered from environmental and equipment samples as well as from raw materials and finished products; the L. monocytogenespositive raw materials were sweet pepper $(n=3)$ and grated cheese $(n=1)$. Visual examination of the AFLP banding patterns of sweet pepper revealed two- to three-fragment differences compared with AFLP profiles of equipment, environmental, or product isolates, whereas grated cheese shared an identical AFLP profile with other isolates of AFLP type A7. A subset of 48 isolates belonging to AFLP type A7 were further analyzed by PFGE. PFGE divided these isolates into two groups; the first group consisted of sweet pepper isolates, and the second group consisted of all other isolates, including an isolate from grated cheese.

Reproducibility. In reproducibility testing, the internal reference L. monocytogenes ATCC 15313 showed identical AFLP banding patterns, based on fragment sizes, during each run. However, small variation in peak heights was observed. Therefore, on the basis of a visual examination of the banding patterns of all strains studied, an $89 \%$ cutoff value was selected to define the AFLP type of L. monocytogenes strains.

\section{DISCUSSION}

The three processing compartments of the chilled food plant had notably different contamination statuses. The 
equipment and environment of compartment I were heavily contaminated with persistent $L$. monocytogenes strains, but the highest number of different AFLP types was detected in compartment II; in compartment III, no contamination of equipment or products was observed.

In compartment I, the cooking step seemed to limit the flow of sporadic L. monocytogenes strains into the postheattreatment area, because only persistent strains were recovered. Both product type and cleaning routines may have predisposed the most contaminated lines, $\mathrm{A}$ and $\mathrm{B}$, to persistent contamination. These lines were used for the production of pizza, and the conveyors were frequently contaminated with pizza fillings, whereas in lines $\mathrm{C}, \mathrm{D}$, and $\mathrm{E}$, the fillings of various bakery products did not come into contact with the conveyors. During high season, pizza was also produced on night shifts, and lines A and B were cleaned only every other day. Because of the attached food particles, the mechanical cleaning of lines A and B was more difficult, which may have favored the persistence of L. monocytogenes. Furthermore, all environmental and equipment isolates of the plant belonged to either serotype $1 / 2$ a or $1 / 2 \mathrm{c}$, both of which have shown increased biofilm formation compared with other serotypes $(6,20)$, and hence, isolates of these serotypes may more often colonize surfaces and resist sanitizing agents. Because lines A and B were situated next to each other, it is also possible that inadequate washing procedures caused splashes, which spread the contamination to the adjacent line. In addition, the new packing machines purchased for these two lines were contaminated with $L$. monocytogenes soon after implementation, while the new packing machine of line E remained free of the organism throughout the surveillance. Unexpectedly, none of the products produced in compartment I tested positive for L. monocytogenes, although some of the contamination sites, such as conveyors, were in direct contact with the products. However, the occasional presence of the organism in finished products cannot be excluded because of the relatively limited number of product samples studied.

The lack of compartmentalization until 2000 may have contributed to the L. monocytogenes contamination status of compartment I. AFLP type A1 was recovered as early as 1998 , when an uncooked product was manufactured in line $\mathrm{B}$, suggesting that the initial contamination may have been introduced to the compartment through raw materials. Although raw and postheat-treatment areas were later separated, the existing L. monocytogenes contamination could not be eliminated. On the other hand, AFLP type A14 was first detected in compartment II and, 3 years later, was observed in compartment I, indicating that contamination by this type may have spread between compartments either via personnel or equipment. Therefore, in compartments that produce cooked meals, special attention should be paid to the separation of raw and postheat-treatment areas. In addition, undesired movement of personnel and equipment between different compartments must be limited by proper compartmentalization and effective hygiene barriers (19).

Compartment II, which produced uncooked chilled food, was contaminated with several persistent and non- persistent strains. The high diversity of strains may result from the range of different raw materials, such as vegetables, meat products, and dairy products, used in production. These ingredients might harbor $L$. monocytogenes $(1,10$, 27, 29), thus introducing the organism to the processing environment. Furthermore, the lack of heat treatment may allow the passage of L. monocytogenes into finished products.

Three grated cheese lots originating from different producers were contaminated with $L$. monocytogenes, suggesting that grating may cause postprocessing contamination of cheese. In compartment II, AFLP type A18 was repeatedly recovered from grated cheese and finished products, indicating that the products were contaminated via raw materials. This is supported by the finding that after the replacement of the cheese supplier, type A18 was no longer detected in the products. However, the same AFLP type was recovered later from a cheese sample of a different producer. This finding is in accordance with Autio et al. (4), who detected identical pulsotypes of $L$. monocytogenes in food products of several producers. AFLP type A7 was first recovered from the uncooked finished products and the cooler of compartment II in September 2000. In December 2000, the same AFLP type was detected in grated cheese. Because the raw materials were not tested for $L$. monocytogenes regularly, the finding raises the question of whether the initial contamination had already been introduced to the plant via grated cheese in September. In addition to cheese, sweet pepper was found to be contaminated with L. monocytogenes several times in the year 2000. To avoid the contamination of finished products, the plant began to cook the sweet pepper before its use in production.

Most of the AFLP types detected in raw materials were sporadic and were not recovered from environmental or equipment samples. Sporadic AFLP types were also detected in uncooked finished products, suggesting that the likely source of contamination of the particular products was raw materials rather than postprocessing contamination by persistent strains on equipment. In compartments that produce uncooked ready meals, special attention should therefore be paid to continuous quality control of raw ingredients, and high-risk raw materials should be heat treated before use in production. Furthermore, consistent highlevel production hygiene must be maintained to avoid the emergence of persistent strains.

Although total elimination of L. monocytogenes from the processing environment may be impossible, comprehensive eradication programs can significantly reduce the level of contamination $(3,5)$. In addition to efficient cleaning, the contamination status can be improved by structural adjustments to the production line. In compartment II, extensive reconstruction of the processing line was conducted in 2005. The line was straightened and made shorter by, for instance, the removal of conveyors. Furthermore, the cooler, which had repeatedly been contaminated with $L$. monocytogenes, was removed from the line. These adjustments resulted in reduced prevalence rates of L. monocytogenes. Moreover, persistent AFLP types A7 and A10 
were not recovered in either environmental or equipment samples after the implementation of structural changes.

In compartment III, only one environmental sample tested positive for L. monocytogenes. The routes by which the organism could have been introduced to the compartment were limited; L. monocytogenes is rarely present in the main raw ingredients (flour and egg) used in this compartment, raw and postheat-treatment areas were clearly separated, and uncooked products had never been produced in the area. The only positive sample contained persistent AFLP type A1 and was detected on a movable container that had been transferred to the compartment without cleaning. Movable containers may thus carry contamination from one compartment to another, and although job rotation was not used between different compartments over the course of a single working day, personnel can indirectly spread the contamination. The transfer of persistent $L$. monocytogenes contamination between food processing plants with a dicing machine has also been reported (18). Thorough cleaning and disinfecting of all machines and equipment before relocation to another compartment or processing plant are therefore essential.

The three most contaminated lines (A, B, and F) of the plant harbored L. monocytogenes, particularly in coolers, conveyors, and packing machines. Machines with poor hygienic design and complex structure are known to favor the persistence of L. monocytogenes (3, 18, 19, 21, 29). Previous studies have also shown that proper cleaning of conveyors is often cumbersome, and therefore, they may harbor Listeria contamination $(21,23,25)$. Because L. monocytogenes was also recovered from surfaces after cleaning and disinfection, the sanitizing practice of the outsourced cleaning service was deemed insufficient to eliminate the organism from equipment. Thus, to improve the level of sanitization, regular monitoring of cleaning service operations is crucial.

AFLP analysis proved to be a fast and reproducible method with high throughput and was thus deemed suitable for contamination route studies. The slight variation seen in band intensities may be a result of differences in the effectiveness of digestion-ligation or PCR amplification reactions (16). The $89 \%$ cutoff value, which served to define the AFLP type, is in accordance with earlier AFLP studies $(8,9,14)$. However, the visual examination of banding patterns of AFLP type A7 revealed that three isolates showed minor fragment differences, and further analysis by PFGE subdivided isolates of type A7 into two distinct clusters. Therefore, the visual examination of banding patterns must not be neglected, although the AFLP analysis can be partly automated. When maximum type differentiation is needed, for instance in outbreak studies, it is also necessary to use a combination of different typing methods (11), to employ more than one primary enrichment medium, and to pick a sufficient number of colonies (28).

In conclusion, long-lasting surveillance and utilization of genotyping methods are essential to get an extensive overview of the contamination status of a food processing plant. In this study, AFLP analysis proved to be an efficient genotyping tool for contamination route studies. We showed that each compartment of the chilled food processing plant had a unique contamination pattern. To prevent the contamination of finished products, identifying contamination sites and initial sources of L. monocytogenes contamination in each compartment separately is necessary. Cleaning routines, product type, and lack of proper compartmentalization appeared to predispose production lines of cooked meals to persistent contamination. In the compartment that produced uncooked foods, the products were also contaminated via raw materials, and hence, the microbial quality of raw ingredients needs to be given more attention. The present study also showed that structural adjustment of the production line may facilitate the eradication of L. monocytogenes.

\section{ACKNOWLEDGMENTS}

This study was supported by the Finnish Graduate School on Applied Bioscience (ABS), the Finnish Veterinary Foundation, and the Walter Ehrström Foundation. We acknowledge Hanna Korpunen for excellent technical assistance.

\section{REFERENCES}

1. Aguado, V., A. I. Vitas, and I. García-Jalón. 2004. Characterization of Listeria monocytogenes and Listeria innocua from vegetable processing plant by RAPD and REA. Int. J. Food Microbiol. 90:341347.

2. Anonymous. 1996. Microbiology of food and animal feeding stuffs-horizontal method for the detection and enumeration of Listeria monocytogenes. Part 1: detection method. ISO method 112901:1996/Amd. 1:2004. International Organization for Standardization, Geneva.

3. Autio, T., S. Hielm, M. Miettinen, A.-M. Sjöberg, K. Aarnisalo, J. Björkroth, T. Mattila-Sandholm, and H. Korkeala. 1999. Sources of Listeria monocytogenes contamination in a cold-smoked rainbow trout processing plant detected by pulsed-field gel electrophoresis typing. Appl. Environ. Microbiol. 65:150-155.

4. Autio, T., J. Lundén, M. Fredriksson-Ahomaa, J. Björkroth, A.-M Sjöberg, and H. Korkeala. 2002. Similar Listeria monocytogenes pulsotypes detected in several foods originating from different sources. Int. J. Food Microbiol. 77:83-90.

5. Autio, T. J., M. K. Lindström, and H. J. Korkeala. 2004. Research update on major pathogens associated with fish products and processing of fish, p. 115-134. In F. J. M. Smulders and J. D. Collins (ed.), Safety assurance during food processing. Wageningen Academic Publishers, Wageningen, The Netherlands.

6. Borucki, M. K., J. D. Peppin, D. White, F. Loge, and D. R. Call 2003. Variation in biofilm formation among strains of Listeria monocytogenes. Appl. Environ. Microbiol. 69:7336-7342.

7. Chasseignaux, E., M.-T. Toquin, C. Ragimbeau, G. Salvat, P. Colin, and G. Ermel. 2001. Molecular epidemiology of Listeria monocytogenes isolates collected from the environment, raw meat and raw products in two poultry- and pork-processing plants. J. Appl. Microbiol. 91:888-899.

8. De Boer, P., B. Duim, A. Rigter, J. van der Plas, W. F. Jacobs-Reitsma, and J. A. Wagenaar. 2000. Computer-assisted analysis and epidemiological value of genotyping methods for Campylobacter jejuni and Campylobacter coli. J. Clin. Microbiol. 38:1940-1946.

9. Duim, B., T. M. Wassenaar, A. Rigter, and J. Wagenaar. 1999. Highresolution genotyping of Campylobacter strains isolated from poultry and humans with amplified fragment length polymorphism fingerprinting. Appl. Environ. Microbiol. 65:2369-2375.

10. Farber, J. M., and P. I. Peterkin. 1991. Listeria monocytogenes, a food-borne pathogen. Microbiol. Rev. 55:476-511.

11. Fonnesbech Vogel, B., V. Fussing, B. Ojeniyi, L. Gram, and P. Ahrens. 2004. High-resolution genotyping of Listeria monocytogenes by fluorescent amplified fragment length polymorphism analysis compared to pulsed-field gel electrophoresis, random amplified poly- 
morphic DNA analysis, ribotyping and PCR-restriction fragment length polymorphism analysis. J. Food Prot. 67:1656-1665.

12. Fonnesbech Vogel, B., H. H. Huss, B. Ojeniyi, P. Ahrens, and L. Gram. 2001. Elucidation of Listeria monocytogenes contamination routes in cold-smoked salmon processing plants detected by DNAbased typing methods. Appl. Environ. Microbiol. 67:2586-2595.

13. Keto-Timonen, R., A. Heikinheimo, E. Eerola, and H. Korkeala. 2006. Identification of Clostridium species and DNA fingerprinting of Clostridium perfringens by amplified fragment length polymorphism analysis. J. Clin. Microbiol. 44:4057-4065.

14. Keto-Timonen, R., M. Nevas, and H. Korkeala. 2005. Efficient DNA fingerprinting of Clostridium botulinum types A, B, E, and F by amplified fragment length polymorphism analysis. Appl. Environ. Microbiol. 71:1148-1154.

15. Keto-Timonen, R. O., T. J. Autio, and H. J. Korkeala. 2003. An improved amplified fragment length polymorphism (AFLP) protocol for discrimination of Listeria isolates. Syst. Appl. Microbiol. 26:236244.

16. Lindstedt, B.-A., E. Heir, T. Vardund, and G. Kapperud. 2000. Fluorescent amplified-fragment length polymorphism genotyping of Salmonella enterica subsp. enterica serovars and comparison with pulsed-field gel electrophoresis typing. J. Clin. Microbiol. 38:16231627.

17. Lundén, J., J. Björkroth, and H. Korkeala. 2005. Contamination routes and analysis in food processing environments, p. 539-555. In H. L. M. Lelieveld, M. A. Mostert, and J. Holah (ed.), Handbook of hygiene control in the food industry. Woodhead Publishing Limited, Cambridge.

18. Lundén, J. M., T. J. Autio, and H. J. Korkeala. 2002. Transfer of persistent Listeria monocytogenes contamination between food-processing plants associated with a dicing machine. J. Food Prot. 65: 1129-1133.

19. Lundén, J. M., T. J. Autio, A.-M. Sjöberg, and H. Korkeala. 2003. Persistent and nonpersistent Listeria monocytogenes contamination in meat and poultry processing plants. J. Food Prot. 66:2062-2069.

20. Lundén, J. M., M. K. Miettinen, T. J. Autio, and H. J. Korkeala. 2000. Persistent Listeria monocytogenes strains show enhanced adherence to food contact surface after short contact times. $\underline{\text { J. Food }}$ Prot. 63:1204-1207.
21. Miettinen, M. K., K. J. Björkroth, and H. Korkeala. 1999. Characterization of Listeria monocytogenes from an ice cream plant by serotyping and pulsed-field gel electrophoresis. Int. J. Food Microbiol. 46:187-192.

22. Pitcher, D. G., N. A. Saunders, and R. J. Owen. 1989. Rapid extraction of bacterial genomic DNA with guanidium thiocyanate. Lett. Appl. Microbiol. 8:151-156.

23. Pritchard, T. J., K. J. Flanders, and C. W. Donnelly. 1995. Comparison of the incidence of Listeria on equipment versus environmental sites within dairy processing plants. Int. J. Food Microbiol. 26:375384.

24. Reij, M. W., and E. D. Den Aantrekker. 2004. Recontamination as a source of pathogens in processed foods. Int. J. Food Microbiol. 91:1-11.

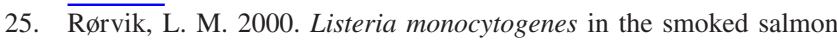
industry. Int. J. Food Microbiol. 62:183-190.

26. Rørvik, L. M., D. A. Caugant, and M. Yndestad. 1995. Contamination pattern of Listeria monocytogenes and other Listeria spp. in a salmon slaughterhouse and smoked salmon processing plant. Int. J. Food Microbiol. 25:19-27.

27. Rudolf, M., and S. Scherer. 2001. High incidence of Listeria monocytogenes in European red smear cheese. Int. J. Food Microbiol. 63: 91-98.

28. $\overline{R y s e r,}$ E. T., S. M. Arimi, M. M.-C. Bunduki, and C. W. Donnelly. 1996. Recovery of different Listeria ribotypes from naturally contaminated, raw refrigerated meat and poultry products with two primary enrichment media. Appl. Environ. Microbiol. 62:1781-1787.

29. Thévenot, D., A. Dernburg, and C. Vernozy-Rozand. 2006. An updated review of Listeria monocytogenes in the pork meat industry and its products. J. Appl. Microbiol. 101:7-17.

30. Vos, P., R. Hogers, M. Bleeker, M. Reijans, T. van de Lee, M. Hornes, A. Frijters, J. Pot, J. Peleman, M. Kuiper, and M. Zabeau. 1995. AFLP: a new technique for DNA fingerprinting. Nucleic Acids Res. 23:4407-4414.

31. Wulff, G., L. Gram, P. Ahrens, and B. Fonnesbech Vogel. 2006. One group of genetically similar Listeria monocytogenes strains frequently dominates and persists in several fish slaughter- and smokehouses. Appl. Environ. Microbiol. 72:4313-4322. 